\title{
Socio-economic Studies of Moringa oleifera L. Leaf Powder added to String Hopper Flour
}

\author{
${ }^{1}$ Harshana P.V.S, ${ }^{2}$ Chamika Sonali, ${ }^{2}$ Sandamali P.V.H, ${ }^{3}$ Asanka Tennakoon, ${ }^{3}$ Salinda Sandamal \\ ${ }^{1}$ Department of Agriculture Economic and Extension, Faculty of Agriculture, Ruhuna University of Sri Lanka \\ Mapalana, Kamburupitiya, Matara, Sri Lanka \\ ${ }^{2}$ Department of Food Science and Technology, Wayamba University of Sri Lanka \\ Makandura, Gonawila, Sri Lanka \\ ${ }^{3}$ Department of Agricultural Biology, Faculty of Agriculture, Ruhuna University of Sri Lanka \\ Mapalana, Kamburupitiya, Matara, Sri Lanka \\ Corresponding Author: saharsha92@gmail.com
}

\section{Manuscript Details}

Manuscript Submitted : 02/07/2018

Manuscript Revised : 09/07/2018

Manuscript Accepted : 24/07/2018

Manuscript Published : 15/09/2018

\section{$\underline{\text { Available On }}$}

https://plantaescientia.uebsite/ojs/ https://doi.org/10.32439/ps.vli03.48-54

\section{Cite This Article As}

Harshana P.V.S, Chamika Sonali, Sandamali PVH, Asanka Tennakoon, Salinda Sandamal (2018) Socio-economic studies of Moringa oleifera L. leaf pouder added to String Hopper Flour, Pla. Sci. 2018; Vol. O1 Issue 02: 48-54.

\section{Copyright}

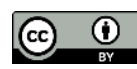

(c) The Author (s). 2018 Open Access

This article is distributed under the terms of the Creative Commons Attribution 4.0 International License http://creativecommons.org/licenses/by/4.0/

\section{$\underline{\text { Indexed In }}$}

Crossref, Index Copernicus International (ICI), Directory of Research Journal Indexing $\underline{(\mathrm{DR} I)}, \underline{\text { Scientific Indexing Services (SIS) }}$

\section{ABSTRACT}

Recently, Moringa oleifera L. leaves substituted string hopper flour has been introduced to the market with regards to renewed consumer trend of healthy eating. However, the way consumer behaves towards this newly introduced product is questionable and hence it needs to be researched. Therefore, this study is mainly focused on the evaluation of the consumer attitudes and acceptance of Moringa added string hopper flour. The study was consisted of a survey to evaluate the consumer attitudes. Moreover, a sensory evaluation was carried out to assess the sensory performance of the particular product. Collected data were mainly analyzed by using SPSS version 16. Interestingly, results showed that the potential health benefits of Moringa remained prominent in the acceptance of the product. Further, sensory results showed appreciable sensory performance allowing consumers to purchase the product with sensorial intention. All the respondents were in satisfactory level regarding the product. The study demonstrates the requirement of popularizing and elevating the availability of the product to achieve better market opportunities in order to widen the market. Current study confirmed that the product exhibits potential of appreciable commercial acceptance and substantial purchasing capacity.

Keywords: Moringa leaves, String hoppers flour, Consumer Preference 


\section{INTRODUCTION}

Foods with potential health-promoting properties are gaining much interest due to consumers' desire for healthy eating (Sabbe et al., 2009). Thus, nutrient-rich various food products are being introduced to the marketplace as a result of the current trend of health-oriented consumers.

Moringa oleifera L. commonly known as drumstick tree or horseradish tree, is the most extensively cultivated species of the genus Moringa, the only genus in the family Moringaceae (Ramachandrant et al., 1980; Anwar et al., 2000). The tree is abundant throughout tropics and subtropics. The plant is being utilized as human food and for medicinal purposes norldwide. Researchers have revealed that leaves, fruits, seeds, floners, bark and roots of the Moringa tree possess numerous benefits that account for both nutritional and medicinal advantages. Due to its enormous health-promoting properties, the plant is universally referred as "the miracle tree".

The leaves, fruits, flowers and immature pods of the tree are consumed in many countries as a highly nutritive vegetable. Nutrient-dense leaves of the tree claimed to be rich in vitamin $\mathrm{E}$ and $\mathrm{C}$, vitamin $\mathrm{A}$ and $\mathrm{D}$, calcium, potassium, phosphorous, iron as well as essential amino acids (Bennett etal., 2003; Aslam etal.,2005; Mbikay, 2012). Moreover leaves serves as a rich source of antioxidants such as ascorbic acid (vitamin C), $\beta$-carotene and flavonoids (Dillard and German, 2000). These phytonutrients involve in free radical scavenging activity and supposed to have immunesuppressive effects. Especially among children and infants, the leaves of the plant have been utilized as an alternative food source against malnutrition (Anwar et al, 2007). Apart from the leaves, fruits and flowers of Moringa contain substantial amounts of carotenoids.

Besides the nutritional benefits, different parts of the tree impart various pharmacological actions hence, Moringa tree plays a vital role in indigenous medicine especially in South Asia. The leaves, fruits, flowers and roots are widely used for treating inflammation and cardiovascular diseases (Ezeamuzle et al., 1996; Limaye et al., 1995; Chumark et al., 2007). Trough animal studies it has revealed that the fruits and leaves of Moringa have hypocholesterolemic activity (Ghasi et al., 2000; Mehta et al., 2003). In addition, unique compounds containing sugar and rhamnose of Moringa reported possessing chemo-preventive activity (Brunelli et al., 2010).

Extensive health-boosting properties of Moringa have raised it for a strong demand. Moreover, application of Moringa in food industries nould be an effective way to convey its health benefits. However, there is no sufficient evidence regarding consumer's attitudes and acceptance towards the particular product. Therefore, it is time required to evaluate consumer's attitudes and acceptance towards the product in order to predict the purchasing capacity. Thus, this study aims to evaluate the consumer's attitudes and acceptance for Moringa substituted string hoppers flour.

\section{LITERATURE REVIEW}

Moringa oleifera L. grous from five to ten meters in height. The tree is abundant throughout the tropics and sub-tropics especially in India, Pakistan, Africa, Arabia, Philippines, Cambodia etc. (Morton, 1991). Due to its deep root system, the tree can survive under inferior fertile soils and well resistant to drought (Anwar et al., 2007). Almost all part of the tree is applicable for medication, food and industrial purposes hence, the tree is reported as one of the norld's most useful trees (Anjorin et al., 2010).

Researchers have revealed that the Moringa tree possesses numerous benefits that account for both nutritional and medicinal advantages. Leaves of the tree serve as a good source of vitamin A, D, E and C, calcium, potassium, phosphorous, iron as vell as essential amino acids (Bennett et al., 2003; Mbikay, 2012;). Such nutrients have the potential for osmotic adjustment; active organic molecules including enzymes and hormones that facilitate grouth, function and maintenance of biological systems (Anjorin et al., 2010). Moringa is claimed to have easily digestible, high quality protein influenced by its amino acids. It has reported the presence of 19 amino acids from 20 common amino acids in dried Moringa leaves (Moyo et al., 2011). Moreover, due to the immense nutritional value of Moringa, it is used to fight malnutrition, especially among infants as well as nursing mothers (Moyo et al., 2011). Seeds and leaves of the plant contain unsaturated fatty acid where oleic is prominent and some saturated fatty acids. According to Khawaja and others (2010), the Moringa was claimed to be "the most nutrient-rich plant yet discovered".

Moringa shows pharmacological properties such as antiinflammatory, antihypertensive, antitumor, antioxidant, anti-ulcer, anti-diabetic and cholesterol-lowering etc. (Palival et al., 2011; Sharma et al., 2012). These pharmacological effects of Moringa are resulted by presences of certain phytochemicals such as flavonoids and phenolic acids (Mbikay, 2012). Different parts of the tree show various pharmacological actions. The leaves, fruits, flowers and roots are widely used for treating inflammation and cardiovascular diseases (Ezeamuzle et al., 1996; Limaye etal., 1995; Chumark et al., 2007). Due to therapeutic effects, Moringa plays a vital role in the medicinal field. It is used to treat various acute and chronic diseases. In addition, unique compounds containing sugar and rhamnose of Moringa reported possessing chemo-preventive activity (Brunelli et al., 2010). Surya wanshi, \& Umate, (2018) have also carreed out phytochemical studies of Moringa. Moreover, Phytomedicines are claimed to be more trustworthy over conventional drugs. Thus, a number of Moringa based products are widely available in the market as a result of grabbing this market opportunity by the food manufacturers. Dried leaves of the plant are marketed for a wide range of health benefits. The phytochemical composition of Moringa has promoted it to use as a food 
supplements. Recently, Moringa is getting much vigilance in food fortification. In addition, many studies have reported the potential of Moringa in food applications such as in making bread (Chinma et al., 2014), herbal biscuits (Alam et al., 2014), yoghurt (Hekmat et al., 2015).

\section{Socio-demographic Characteristics of the Respondents}

A total of 50 Moringa String hoppers consumers nere invited to be part of the survey and all participants completed the questionnaires with a response rate of $100.0 \%$. Table 1 shows

Table 1. Socio-demographic information of the respondents

\begin{tabular}{|c|c|c|c|}
\hline Category & Component & Frequency & Percentage (\%) \\
\hline \multirow{4}{*}{ Age in years } & $20-29$ & 18 & 36 \\
\hline & $30-39$ & 16 & 32 \\
\hline & $40-49$ & 7 & 14 \\
\hline & $50-59$ & 9 & 18 \\
\hline \multirow{2}{*}{ Gender } & Male & 38 & 76 \\
\hline & Female & 12 & 24 \\
\hline \multirow{2}{*}{ Area } & Rural & 38 & 76 \\
\hline & Urban & 12 & 24 \\
\hline \multirow{3}{*}{ Educational achievements } & Primary & 29 & 58 \\
\hline & Secondary & 8 & 16 \\
\hline & Degree/ Diploma & 13 & 26 \\
\hline
\end{tabular}

\section{METHODOLOGY}

The study consists of tho parts; a sensory evaluation and survey. A sensory evaluation of Moringa substituted string hoppers with conventional string hoppers was carried out to examine the sensory performance of the product. A survey was conducted to examine of consumer's perception towards the particular product.

The target population of the study was general public in Malabe area. The 80 participants were selected purposively, which comprised of Moringa string hoppers consumers with unequal gender distribution. The empirical data for the study were gathered through a well- structured questionnaire, which was distributed among Moringa string hoppers consumers who purchase within their household.

For the sensory evaluation, simple preference test was employed with the help of 30 untrained panellists. A 9 point hedonic scale was used to evaluate the string hoppers samples for appearance, colour, odour and texture. Conventional white string hoppers served as the control. The control for sensory evaluation was selected by based on the evidence of the survey. Mostly consumed string hopper product of a reputed brand was used as the control.

Descriptive methods of analysis nere followed using SPSS Version 16 statistical software to analyze the data. In statistical analysis, the value of $\mathrm{p}<0.05$ was selected as to be statistical significance.

\section{RESULTS}

the socio-demographic characteristics of the respondents. Majority of the respondents were female (76.0\%). Most of the respondents $(36.0 \%)$ were laid in the youngest age category within 20-29years. The age of the participant's ranges $20-55$ years. $76.0 \%$ of participants were from rural areas and the majority of them (58.0\%) achieved a primary education.

\section{Examination of Awareness for the Product}

The questionnaire was distributed only among Moringa string hoppers consumers and they were asked to comment on how they were aware of the particular product (Figure 1). Majority of them (74.0\%) were aware through word of mouth (WOM) and the product had been introduced to $26 \%$ of the participants by their friends. None of the respondents was aware through neuspaper or television advertisements.

The participants were asked to give their opinion on purchasing Moring added string hopper flour. It revealed that $94 \%$ of the string hoppers consumers had purchased the particular product due to the immense nutritional benefits of Moringa leaves which serves as an ingredient of the product. The rest $(26 \%)$ had consumed the product mainly due to its sensory pleasure. Further, participants were asked to render the most frequently buying string hopper flour product from the market (Figure 2). The most frequent type of string hopper flour purchased reported by 46 (92\%) respondents were white string hopper flour. The second highly consumed string hopper flour type was shown by 3 (6\%) as Moringa string hopper flour. Meanuhile, the majority 
(92\%) of the respondents purchase goods from wayside boutique while $8 \%$ of them purchase goods from supermarkets.

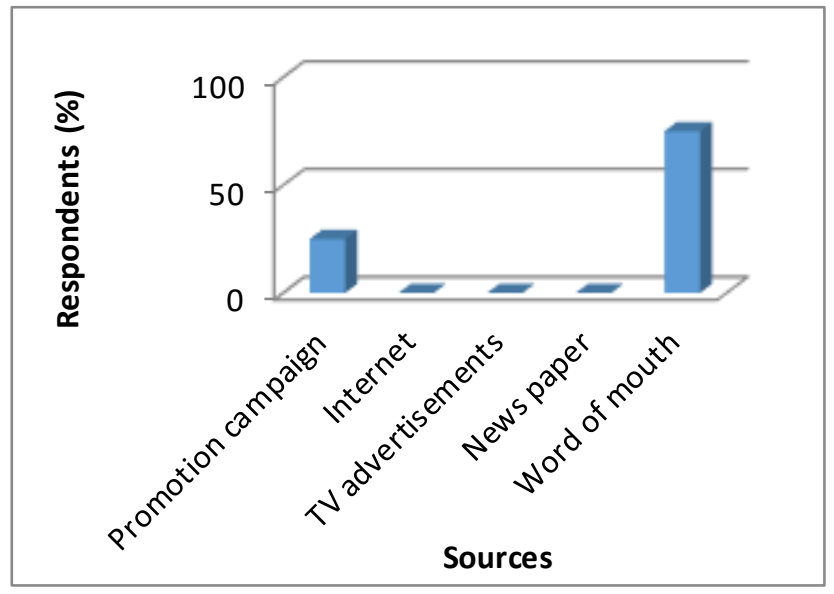

Figure l. Respondent's awareness technique on the product.

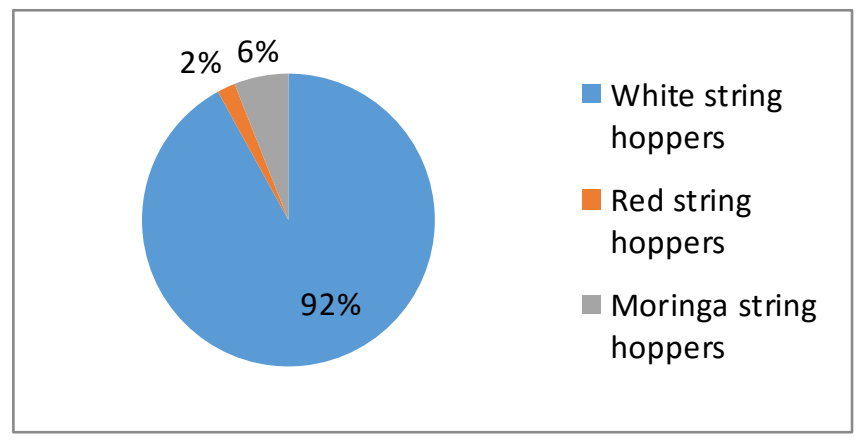

Figure 2. Type of frequently consumed string hopper flour

\section{Evaluation of Consumer Satisfaction}

Participants were examined for their satisfaction level with respect to price, availability and package of Moringa string hopper flour (Figure 3). The results indicate the majority of the respondents were in satisfactory level with regards price of the product. However, slightly greater than half (54\%) of participants were unsatisfied regarding the package of the product whilst all of them are unsatisfied regarding the availability of the product. Moreover, participants were examined for their overall satisfaction with the product. It was reported that all of the participants $50(100 \%)$ were in satisfactory level with respect to the product. Further, it was

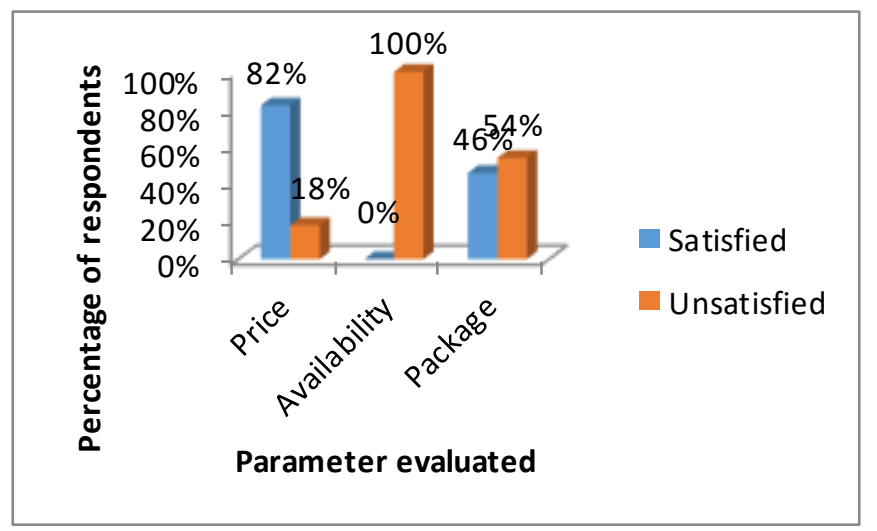

determined that $94 \%$ of the respondents aware of health benefits of Moringa.

Figure 3. Satisfactory levels of the respondents

\section{Sensory Evaluation}

The scale used for the evaluation was prepared by giving 1 for extremely dislike option and 9 for extremely like the option to select sensory qualities. Data were analyzed via Wilcoxon Sign Rank test. The assumption had made as the value of p should be lesser than 0.05 to be significant. Results had been taken with a 95\% confidence level.

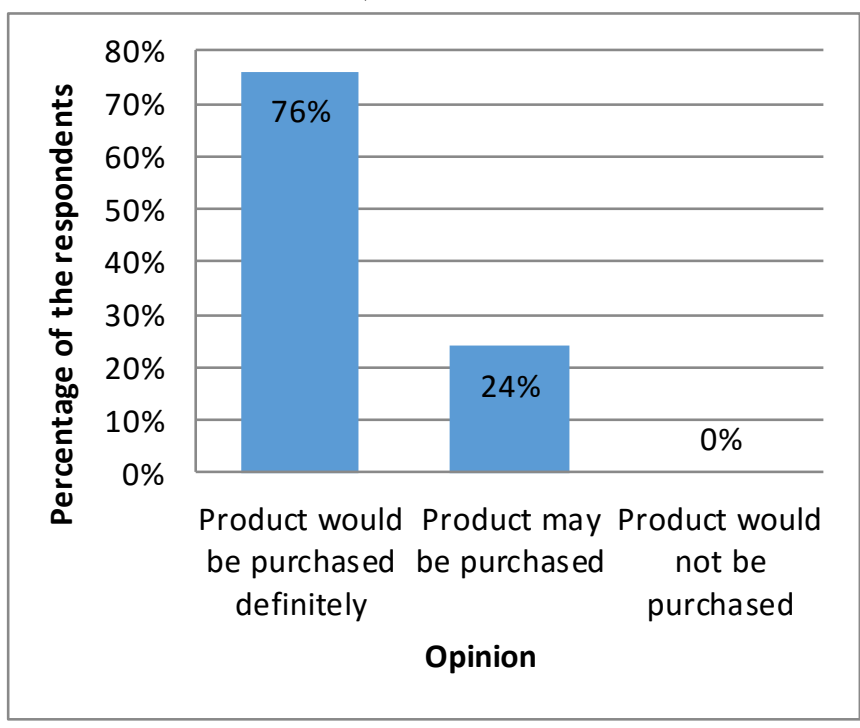

Figure 4. Opinion on purchase with regards to the sensory performance of the new product

Table 2. Results of Wilcoxon Sign Rank test for sensory attributes of selected string hoppers

\begin{tabular}{l|l|l|l|l|l|l|}
$\begin{array}{l}\text { Type of } \\
\text { String } \\
\text { Hopper }\end{array}$ & $\begin{array}{l}\text { Mppe } \\
\text { aranc } \\
\text { e }\end{array}$ & Color & $\begin{array}{l}\text { Text } \\
\text { ure }\end{array}$ & Odor & Taste & $\begin{array}{l}\text { Overall } \\
\text { accepta } \\
\text { nce }\end{array}$ \\
\hline $\begin{array}{l}\text { White } \\
\text { String } \\
\text { Hopper }\end{array}$ & 7.37 & 6.97 & 7.10 & 6.70 & 7.03 & 6.90 \\
\hline $\begin{array}{l}\text { Moringa } \\
\text { String } \\
\text { Hopper }\end{array}$ & 7.33 & 7.40 & 6.87 & 6.60 & 7.03 & 7.20 \\
\hline Palue & 0.988 & 0.109 & 0.467 & 0.873 & 0.757 & 0.225 \\
\hline
\end{tabular}

$\mathrm{P}$ values for all tested characteristics were greater than 0.05 hence, results revealed a similarity between the samples with respect to the evaluated sensory attributes. Furthermore, With respect to the sensory performance of the product, participants commented on whether they 
purchase the product or not. Results depicted that the highest percentage of the respondents $(76 \%)$ were willing to buy the product definitely and none of the respondents willing to not to buy the product.

\section{DISCUSSION}

In the present study, it has investigated commercial acceptance and consumer attitudes for Moringa mixed string hopper flour. Recently, Moringa is getting much vigilance in food industrial application due to solid demand for healthy foods. Today people are more sophisticated and health conscious. Thus, products those address consumers' health may achieve better market opportunities.

Generally, use of broadcast media and internet are considered as indispensable advertising strategies. Such media can effectively communicate to mass making more immediate purchases. In addition, it has revealed that attitudes formed through repeated ad exposure are same as those formed through direct experience and they are highly accessible from memory (Berger and Mitchell, 1989). Even though broadcast media and internet available organization were not use promote the product via that media. Advertising provides ground for the product which is newly introduced or launch in the market. However, the company did not possess a defined advertising mechanism to make aware the public regarding the product. This may negatively affect to the purchasing capacity of the product since customers buy products mostly after they are made aware of the product. Thus it nould be beneficial to advertise the product to create goodwill and increase sales of the product. Findings of this study suggested the requirement of advertising the product. Meanwhile, WOM is considered to be a powerful marketing tool which posits customer to customer communications. It is a strong recommendation from a trusted source to use the product. Literature has shown that both customer satisfaction and trust have a positive association with WOM (Ranaweera and Prabhu, 2003). In this study, the majority was aware through WOM. It implies that the product had made the consumers satisfied. This could be due to unique composition and potential health benefits of the product over conventional string hopper flour.

Recently, there is a great interest in nutritional properties of Moringa in many countries (Sánchez et al., 2006; Owusu et al., 2008). Rice flour serves as the main ingredient of conventional string hopper flour. The new product contains dry Moringa leaf ponder in addition to rice flour. It has revealed that dry Moringa leaves contain protein including essential amino acids, minerals (Calcium, Potassium, Phosphorus, Selenium and Iron), fatty acids including $\alpha$ linolenic acid, Vitamin $\mathrm{E}$ in considerable amounts (Moyo et al., 2011). Such a nutrient composition can attract consumers towards the product. Since nutritional properties are invisible, it is important to communicate healthiness of the product via health and nutrition information labels or claims otherwise remain hidden or unknown to interest customers (Trijp and Lans, 2007; Williams, 2005; Sabbe et al., 2009).
Moreover, health claims and nutritional benefits are extensively used in marketing strategies and affect consumer $s$ ' choice. People who are health conscious give the forefront to nutritional and health benefits of the product besides its sensory pleasure (Sabbe et al., 2009). This finding is in line with the current study. The majority had purchased the new product with the health intention. Thus, the perception of better nutrition properties of the new product may increase the consumer acceptance.

Apart from the nutritional value, sensory quality of the product acts as a major determinant in customer choice. Though the claimed health benefits add value to the product, customers cannot be satisfied with inferior sensory performances (Bechlarsen and Scholderer, 2007). According to Tuorila and Cardello (2002) presence of off-flavours affects consumers' likelihood of a product besides its health benefits. In this respect, sensory evaluation of the product vas done against mostly consumed string hopper type in the local market. Results of the sensory analysis depicted appreciable sensory performance of the product. Moreover, with regards to the sensory performance of the product majority commented they nould buy the product definitely. These findings imply potential of good demand for the product.

Price and the package have been regarded as crucial factors of customer choice. Appropriate or fair prices attract more consumers to buy the product. This study suggested a price of the product was in satisfactory level but the package of the product should be further improved. Since the package of the product seemed to be less attractive. Moreover, findings of the current proposed some strategies towards elevating consumer acceptance and the purchasing capacity of the new product as increasing the availability of the product in the consumer market, popularizing the product via advertising. The study revealed the majority are buying goods from retail shops. Hence product should be more available in retail shops. Apart from advertising the product can be popularized by introducing it to restaurants, encouraging vendors to promote the product, participation in TV programs etc.

\section{CONCLUSION}

The current study contributes to the understanding of consumer attitudes and acceptance of Moringa leaves powder substituted string hopper flour. A proper understanding of consumer acceptance and attitudes of the product drive it towards better market opportunities while widening the market. The study confirms that the product exhibits potential of appreciable commercial acceptance and better purchasing capacity. Consumer acceptance and intention to buy Moringa leaves ponder substituted string hopper flour is driven most by health-boosting properties of Moringa. In addition to the nutritional claims, the product shous better sensory performances. Moreover, the findings of the study suggest in order to increase the purchasing capacity of the product; it should be made more available in the consumer market, the product should be further popularized through proper marketing strategies. 


\section{REFERENCES}

Alam, A., Alam, J., Hakim, A., Huq, A.O. and Moktadir, S.G., (2014). Development of fiber enriched herbal biscuits: A preliminary study on sensory evaluation and chemical composition. International Journal of Nutrition and Food Sciences, 3(4), pp.246-250. doi: 10.11648/j.ijnfs. 20140304.13

Anjorin, T.S., Ikokoh, P. and Okolo, S., (2010). Mineral composition of Moringa deifera leaves, pods and seeds from two regions in Abuja, Nigeria. International Journal of Agriculture and Biology, 12 (3), pp. 431-434.

Anwar, F., Latif, S., Ashraf, M. and Gilani, A.H., (2000). Moring a deifera: a food plant with multiple medicinal uses. Phytotherapy research, 2l(1), pp.17-25. https://doi.org/10.1002/ptr.2023

Aslam, M., Anwar, F., Nadeem, R, Rashid, U., Kazi, T.G. and Nadeem, M., (2005). Mineral composition of Moringa deifera leaves and pods from different regions of Punjab, Pakistan. Asian Journal of Plant Sciences. DOI: https://doi.org/10.3923/ ajps. 2005.417.421

Bech-Larsen, T., \& Grunert, K. G. (2003). The perceived healthiness of functional foods. A conjoint study of Danish, Finnish and American consumers' perception of functional foods. Appetite, 40, 9-14 https://doi.org/10.1016/ S0195-6663(02)00171-X

Bennett, R.N., Mellon, F.A., Foidl, N., Pratt, J.H., Dupont, M.S., Perkins, L. and Kroon, P.A., (2003). Profiling glucosindlates and phendics in vegetative and reproductive tissues of the multi-purpose trees Moringa deifera L.(horseradish tree) and Moringa stenopetala L. Journal of agricultural and food chemistry, 51(12), pp.3546-3553. DOI: $10.1021 /$ jf0211480

Berger, I.E. and Mitchell, A.A., (1989). The effect of advertising on attitude accessibility, attitude confidence, and the attitude-behavio relationship. Journal of Consumer Research, 16(3), pp.269279. https://doi.org/10.1086/209213

Brunelli, D., Tavecchio, M., Falcioni, C., Frapolli, R., Erba, E., Iori, R, Rollin, P., Barillari, J., Manzotti, C., Morazzoni, P. and D'Incalci, M, (2010). The isothiocyanate produced from glucomoringin inhibits NF-kB and reduces myeloma growth in nude mice in vivo. Biochemical pharmacology, 79 (8), pp.1141-1148. https://doi.org/10.1016/ j.bcp. 2009.12.008

Chinma, C.E., Abu,J.O. and Akoma, S.N., (2014). Effect of Germinated Tigernut and Moring a Flour Blends on the Quality of Wheat-Based Bread. Journal of food processing and preservation, 38(2), pp.721-727. https://doi.org/10.1111/jfpp.12023

Chumark, P., Khunawat, P., Sanvarinda, Y., Phornchirasilp, S., Morales, N.P., Phivthong-ngam, L., Ratanachamnong, P., Srisawat, S. and Klaiupsorn, S.P., (2008). The in vitro and ex vivo antioxidant properties, hypolipidaemic and antiatherosclerotic activities of water extract of Moringa deifera Lam. leaves. Journal of ethnopharmacology, 116(3), pp. 439 446. https://doi.org/10.1016/j.jep. 2007.12.010

Dillard, C.J. and German, J.B., (2000). Phytochemicals: nutraceuticals and human health. Journal of the Science of Food and Agriculture, 80(12), pp.1744-1756. https://doi.org/10.1002/1097-

0010(20000915)80:12<1744::AID-JSFA725 $3.0 . C O ; 2-W$

Ezeamuzie, I.C., Ambakederemo, A.W., Shode, F.O. and Ekwebelem, S.C., (1996). Anti-inflammatory effects of Moring a deifera root extract. International Journal of Pharmacognosy, 34(3), pp. 207-212. https://doi.org/10.1076/ phbi.34.3.207.13211

Ghasi, S., Nwobodo, E. and Ofili, J.O., (2000). Hypocholesterolemic effects of crude extract of leaf of Moringa deifera Lam in high-fat diet fed Wistar rats. Journal of Ethnopharmacology, 69(1), pp.21-25. https://doi.org/10.1016/ \$0378-8741(99)00106-3 Guerrero, L., Colomer, Y.j, Guàrdia, M.D., Xicola, J. and Clotet, R,
(2000). Consumer attitude towards store brands. Food Quality and Preference, 11(5), pp. 387-395. https://doi.org/10.1016/ \$0950-3293(00)00012$\underline{4}$

Hekmat, S., Morgan, K, Soltani, M. and Gough, R, (2015). Sensory evaluation of locally-grown fruit purees and inulin fibre on probiotic yogurt in mwanza, Tanzania and the microbial analysis of probiotic yogurt fortified with Moringa deifera. Journal of health, population, and nutrition, 33(1) p. 60 .

Khawaja TM, Tahira M, IkramUK( 2010). Moring a deifera: a natural giftA review. J Pharm sci Res, 2, 775-81.

Limaye, D.A., Nimbkar, A.Y., Jain, R. and Ahmad, M., (1995).

Cardiovascular effects of the aqueous extract of Moring a pteryg osperma. Phytotherapy Research, 9(1), pp.37-40. https://doi.org/10.1002/ptr.2650090109

Mbikay, M., (2012). Therapeutic potential of Moringa deifera leaves in chronic hyperglycemia and dyslipidemia: a review. Frontiers in pharmacology, 3. https://doi.org/10.3389/fphar.2012.00024

Mehta, K, Balaraman, R, Amin, A.H., Bafna, P.A. and Gulati, O.D. (2003). Effect of fruits of Moring a deifera on the lipidprofile of normal and hypercholesterdaemic rabbits. Journal of ethnopharmacology, 86(2), pp.191-195. https://doi.org/10.1016/50378-8741(03)00075-8

Morton, J.F., (1991). The horseradish tree, Moringa pterygosperma (Moring aceae) - a boon to arid lands?. Economic botany, 45(3), pp.318-333. $\underline{\text { https:// doi. org/10.1007/BF02887070 }}$

Moyo, B., Masika, P.J., Hugo, A. and Muchenje, V., (2011) Nutritional characterization of Moringa (Moringa deifera Lam.) leaves. African Journal of Biotechnology, 10(60), pp.12925-12933 https://doi. org/l0.5897/AJBl0.1599

Owusu, D., Ellis, W.O. and Oduro, I., (2008). Nutritional potential of two leafy vegetables: Moring a deifera and Ipomøa batatas leaves.

Paliwal, R., Sharma, V., Pracheta, S.S., Y adav, S. and Sharma, S.H., (2011) Anti-nephrotoxic effect of administration of Moringa deifera Lam in amelioration of DMBA-induced renal carcinogenesis in Swiss albino mice. Biology and Medicine, 3(2), pp. 27-35.

Ramachandran, C., Peter, K.V. and Gopalakrishnan, P.K, (1980). Drumstick (Moringa deifera): a multipurpose Indian vegetable. Economic botany, 34(3), pp.276-283. https:// doi.org/10.1007/ BF0285864

Ranaweera, C. and Prabhu, J., (2003). On the relative importance of customer satisfaction and trust as determinants of customer retention and positive word of mouth. Journal of Targeting, MeasurementandAnalysis for marketing, 12(1), pp. 82-90. https:// doi.org/10.1057/ palgrave.jt. 5740100

Sabbe, S., Verbeke, W., Deliza, R., Matta, V. and Van Damme, P., (2009) Effect of a health claim and personal characteristics on consumer acceptance of fruit juices with different concentrations of açaí (Euterpe deracea Mart.). Appetite, 53(1), pp.84-92. https://doi.org/10.1016/j.appet.2009.05.014

Sánchez, N.R, Spörndly, E. and Ledin, I., (2006). Effect of feeding different levels of foliage of Moring a deifera tocrede dairy cows on intake, digestibility, milk production and composition. Livestock Science, 101(1), pp. 24-31. https://doi.org/10.1016/j.livprodsci.2005.09.010

Sharma, V., Paliwal, R., Janmeda, P. and Sharma, S., (2012) Renoprotective effects of Moring a deifera pods in 7, 12-dimethylbenz[a] anthracene-exposed mice. Zhong xi yi jie he xue baoJournal of Chinese integrative medicine, 10 (10), pp.1171-1178.

https://doi. org/10.3736/jcim20121015

Survawanshi. V.. \& Umate. S. (2018). Phvtochemical Screening of Flowers from Moringa deifera Lam. Plantae Scientia, 1(01), 31-35. https://doi. org/10.32439/ps.vli0l.31-35 
Tuorila, H., \& Cardello, A. V. (2002). Consumer responses toan off-flaver in juice in the presence of specific health claims. Food Quality and Preference, 13, 56-569. https://doi.org/10.1016/S0950-3293(01)00076-3

Van Trijp,H. C. M., \& van der Lans, I. A. (2007). Consumer perceptions on nutrition and health claims. Appetite, 48, 299-308 https://doi.org/10.1016/ j.appet.2006.09.011

Verbeke, W.,(2005). Consumer acceptance of functional foods: socio demographic, cognitive and attitudinal determinants. Food quality and preference, 16(1), pp.45-57. https://doi.org/10.1016/j.foodqual.2004.01.001

Williams, P. (2005). Consumer understanding and use of health claims for foods. Nutrition Reviews, 63, 256-264. https://doi.org/10.111//j.1753 4887.2005.tb00382.x

(C) 2018| Published by Plantae Scientia 